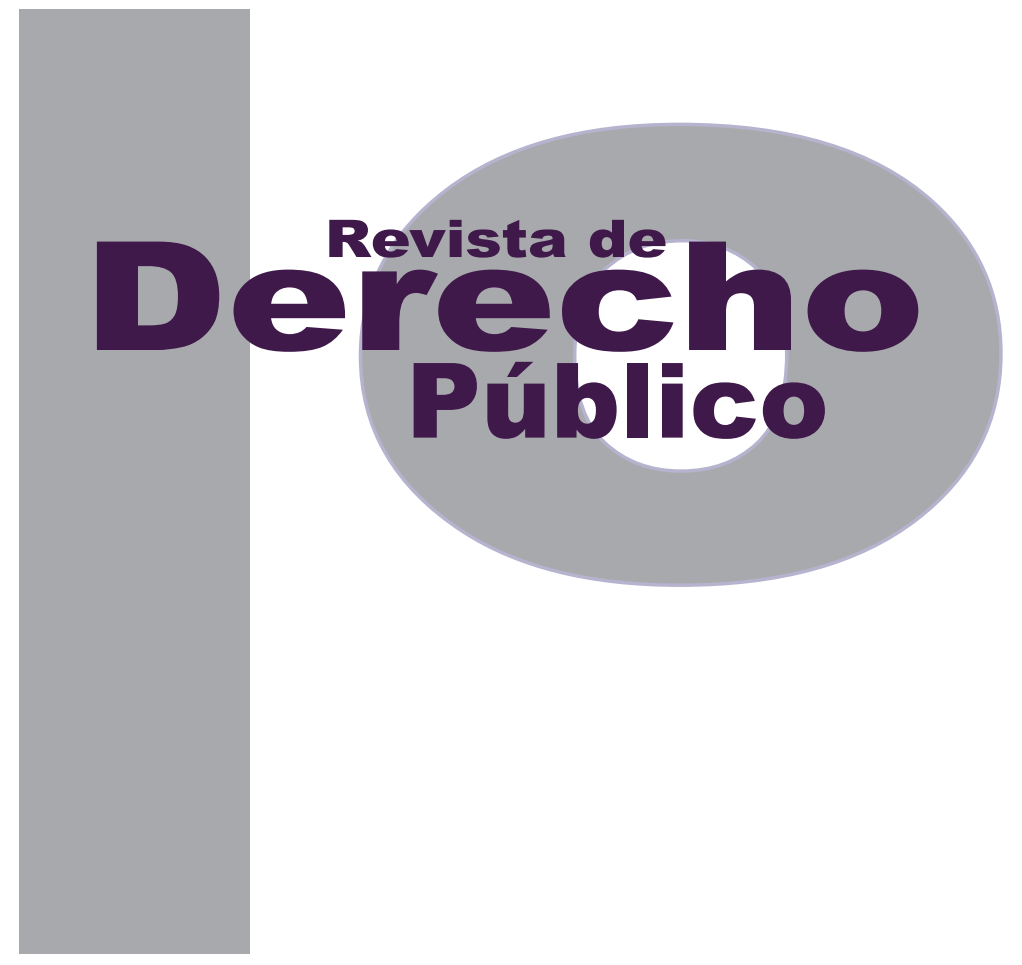

\title{
LOS EFECTOS JURÍDICOS DE LA DECLARATORIA DE UNA ZONA EXCLUIBLE DE LA MINERÍA RESPECTO DE LOS TÍTULOS MINEROS OTORGADOS CON ANTERIORIDAD A ELLA
}

María Lucía Amador Mesa

Universidad de los Andes

Facultad de Derecho

Revista de Derecho Público N. ${ }^{\circ} 29$

Julio - Diciembre de 2012. ISSN 1909-7778 


\title{
Los efectos jurídicos de la declaratoria de una zona excluible de la minería respecto de los títulos mineros otorgados con anterioridad a ella
}

\author{
María Lucía Amador Mesa*
}

\begin{abstract}
Colombia's legal system excluded from the mining activity certain conservation areas that could suffer irreversible damage and therefore, they should be kept outside of these activities. However, currently there is no coordination between mining and environmental policies in Colombia and therefore there are several cases in which these conservation areas overlap with mining titles that were granted previously. Tthis document analyzes the consequences that result from the declaration of an excludable zone from mining activity over the mining titles present in the area and projects the possible solutions to accomplish a balance between the interests that result in conflict.
\end{abstract}

KEYWORDS: excludable zone from mining activity, mining concession contract, mining title, acquired rights, legitimate expectations principle, foreign investment.

\section{RESUMEN}

El sistema jurídico colombiano sustrajo de la actividad minera algunas zonas de conservación ambiental que podrían llegar a deteriorarse con las labores mineras y que deberían conservarse fuera de estas actividades en forma absoluta. Sin embargo, actualmente no existe una coordinación entre los sectores minero y ambiental y por eso hay superposiciones de estas zonas con títulos mineros vigentes que fueron otorgados con anterioridad. El presente trabajo pretende analizar cuáles son las consecuencias que trae la declaratoria de una zona excluible de la minería sobre los títulos mineros vigentes en el área y esbozar las posibles soluciones para lograr un equilibrio entre los sectores en conflicto.

Palabras clave: zona excluible de la minería, contrato de concesión minera, título minero, derechos adquiridos, principio de confianza legítima, inversión extranjera.

Abogada de la Universidad de los Andes. Jefe de prensa y comunicaciones de la Embajada de Colombia en Estados Unidos. Correo: mlamador60@ gmail.com. Este artículo es producto del trabajo de pregrado dirigido por la doctora Margarita Ricaurte de Bejarano. 


\section{SUMARIO}

Introducción - I. CONTEXTO: ACTUALIDAD DEL SECTOR MINERO EN COLOMBIA - II. EL CONTRATO DE CONCESIÓN MINERA EN COLOMBIA - A. Definición y características - B. Etapas del contrato - 1. Exploración - 2. Construcción y montaje - 3. Explotación - III. ZONAS EXCLUIBLES DE LA MINERÍA A. Fundamentos para la existencia de las zonas excluibles de la minería - B. El régimen legal de las zonas excluibles de la minería - 1. Prohibición - 2. Áreas de exclusión y reglas para su delimitación y declaración - 3. Explotación excepcional - 4. Régimen de transición - IV. EFECTOS DE LA DECLARATORIA DE UNA ZONA EXCLUIBLE DE LA MINERÍA SOBRE LOS TÍTULOS MINEROS PREEXISTENTES EN LA ZONA - A. Principios - 1. Derechos adquiridos y meras expectativas - 2. Confianza legítima - 3. Protección a la inversión extranjera - 3.1. Trato justo y equitativo - 3.2. Expropiación indirecta - B. Escenarios en los que podría encontrarse un título minero cuando se declara un área excluible de la minería en la zona - 1. Título minero con licencia ambiental aprobada y que se encuentre en etapa de construcción y montaje o explotación - 2. Título minero que ha presentado el Plan de Trabajos y Obras junto con el Estudio de Impacto Ambiental y su licencia ambiental se encuentra en trámite - 3. Título minero en etapa de exploración - V. CONCLUSIONES - Bibliografía. 


\section{Introducción}

Según el economista Germán Sánchez Pérez (2002, p. 79), en Colombia, como en cualquier país, "el modelo de desarrollo adoptado determina en cierta medida cómo el sector productivo se interrelaciona e influye en el medio ambiente y los recursos naturales". Con el fin de estimular el desarrollo económico del país y en especial para fomentar la inversión en el sector minero, el artículo 13 de la Ley 685 de 2001, por medio de la cual se expidió el Código de Minas, previó como actividad de utilidad pública e interés social la industria minera en todas sus ramas y fases.

Sin embargo, el aprovechamiento de los recursos no ha sido el más adecuado y, por ello, eventualmente podríamos llegar a enfrentar una crisis de agotamiento de los recursos naturales. Por esta razón, expertos en medio ambiente y sostenibilidad se han cuestionado acerca de los impactos de los proyectos mineros que se están llevando a cabo y que se aproximan "y sobre si es posible hablar de una minería responsable y sostenible". (Alianzas para la Sostenibilidad, s. f.).

Teniendo en cuenta lo anterior, el sistema jurídico colombiano sustrajo de la actividad minera algunas zonas que podrían destruirse o deteriorarse con las obras y labores de la minería y que deberían conservarse fuera de estas actividades en forma absoluta (Consejo de Estado. Sección Tercera, Sentencia del 23 de junio de 2010). La Ley 685 de 2001, consagró en su artículo 34 la prohibición de ejecutar obras y trabajos de exploración y explotación minera en ciertas "zonas declaradas y delimitadas conforme a la normatividad vigente como de protección y desarrollo de los recursos naturales renovables o del ambiente". Las zonas de exclusión que comprende el artículo son las que integran el Sistema de Parques Nacionales Naturales, los parques naturales de carácter regional y las zonas de reserva forestal. Ahora bien, la Ley 1382 de 2010 modificó algunos de los preceptos contenidos en el Código de Minas de 2001, incluido el artículo en mención, al que además de las zonas de exclusión ya contempladas adicionó dentro de estas los ecosistemas de páramo y los humedales designados dentro de la lista de importancia internacional de la Convención Ramsar.

Si bien el Código de Minas prevé esa prohibición de manera expresa, lo cierto es que en la actualidad existen más de 750 títulos en estas zonas y hay más de 2000 solicitudes en trámite (Ministerio de Ambiente, Vivienda y Desarrollo Territorial, 2010). Es claro que en la práctica existe un conflicto entre la búsqueda de la protección al medio ambiente y la actividad minera, pues se están otorgando títulos y declarando áreas sin existir una coordinación entre las autoridades encargadas. La realidad, entonces, dista mucho de acogerse a la legalidad.

El presente documento busca analizar la problemática que surge cuando un particular tiene un título minero sobre determinada área y dicha área, o parte de ella, es después declarada como una zona excluible de la minería, según aquellas contempladas en el artículo 34 del Código de 
Minas y sus reformas. El trabajo se enfocará en los efectos jurídicos que tiene dicha declaratoria sobre los títulos mineros existentes y otorgados legalmente en el área con anterioridad a su declaratoria. Para abordar el tema propuesto se procederá de acuerdo con el esquema que se plantea a continuación. En primer lugar se hará una exposición de la actualidad del sector minero en Colombia para entender la importancia que ha adquirido la tensión entre el medio ambiente y la actividad minera, eje central del presente trabajo. Así mismo, se hará un esbozo general sobre el contrato de concesión minera y las obligaciones que surgen de cada una de las etapas de este, lo que resulta de vital importancia para el análisis que se realizará posteriormente. Como segunda medida, se analizará de manera detallada la prohibición contenida en el artículo 34 del Código de Minas y sus reformas, para entender exactamente el régimen aplicable a las zonas excluibles de la minería. Posteriormente, teniendo en cuenta que el problema de investigación planteado no encuentra solución en las leyes que rigen la materia, es necesario hacer un análisis de la situación utilizando teorías constitucionales y principios del derecho administrativo. Por esta razón, se hará como primera medida un análisis doctrinal y jurisprudencial de los conceptos de derecho adquirido, mera expectativa y confianza legítima, así como de los principios protectores de la inversión extranjera de trato justo y equitativo y expropiación indirecta, para luego sí determinar los efectos que tiene la declaratoria de una zona excluible de la minería sobre los títulos mineros preexistentes, dependiendo de la etapa en la que se encuentre la ejecución del contrato y utilizando los principios expuestos anteriormente. Finalmente se plantearán las conclusiones derivadas del estudio presentado, para proponer algunas consideraciones que deben ser tenidas en cuenta a la hora de regular las restricciones territoriales de la actividad minera.

\section{CONTEXTO: ACTUALIDAD DEL SECTOR MINERO EN COLOMBIA}

Durante los últimos años, la minería ha apuntado a convertirse en una de las principales actividades económicas de Colombia. En el año 2010, el "boom minero", que ya venía creciendo y fortaleciéndose, se hizo público cuando el presidente Juan Manuel Santos anunció que la minería sería una de las cinco locomotoras del desarrollo, lo que fue determinante para convertir al país en una potencia minera (Otero, 2012, p. 2).

Actualmente el sector minero ocupa el segundo lugar como receptor de inversión extranjera en Colombia, después del sector de hidrocarburos (Bejarano y Cárdenas, 2012). Además, según la ong Peace Brigades International (2011, p. 3), más del 40\% del territorio nacional está concesionado o solicitado por multinacionales para realizar proyectos de extracción de minerales e hidrocarburos. Sin embargo, debido a ese afán por recibir inversiones extranjeras para el desarrollo de estas actividades, el sector minero viene atravesando por un periodo de duros cuestionamientos, pues se han presentado irregularidades en el otorgamiento de algunos 
títulos mineros concedidos en el territorio nacional: expedición de títulos en los que se dio trámite privilegiado a solicitudes de particulares en detrimento de los intereses de comunidades mineras tradicionales, inconsistencias en los datos del Registro Minero, especulación de títulos, expedición de títulos superpuestos con áreas de protección ambiental, acumulación de solicitudes en cabeza de muy pocos solicitantes y anomalías en la contratación, entre otros (Ingeominas, 2011).

El deterioro ambiental generado por la minería ya se está haciendo evidente pues se ha dado prioridad a la extracción de minerales, sin antes definir en qué áreas del país es posible o no hacerlo y qué impactos ambientales generan los proyectos. Según el ambientalista Manuel Rodríguez Becerra (2012), “la forma en que se están otorgando los títulos mineros y bloques petroleros implica en la práctica que estas dos actividades están predeterminando el ordenamiento ambiental del territorio".

Si bien el Código de Minas de 2001 y sus reformas consagran la prohibición de desarrollar actividades mineras en ciertas zonas de protección ambiental, lo cierto es que la situación actual del país dista mucho de acogerse a la ley. Según datos del antiguo Ministerio de Ambiente, Vivienda y Desarrollo Territorial (2010), la autoridad minera ha expedido 2122 títulos mineros en zonas excluibles de la minería y actualmente existen más de 6400 solicitudes en trámite:

\begin{tabular}{|c|c|c|c|c|}
\hline Área protegida & Área total (ha) & $\begin{array}{c}\text { Área afectada por } \\
\text { títulos (ha) }\end{array}$ & $\%$ & №. de títulos \\
\hline Parque Nacional Natural & 10.421 .513 & 45.175 & $0,4 \%$ & 45 \\
\hline Parque Nacional Regional & 51.497 & 251 & $0,5 \%$ & 5 \\
\hline Zona de Reserva Forestal Protectora & 468.593 & 264.140 & $56,4 \%$ & 327 \\
\hline Zona de Reserva Forestal de la Ley $2^{\text {da }}$ & 43.801 .089 & 6.685 .556 & $46,8 \%$ & 1.181 \\
\hline Ecosistemas de páramo & 1.187 .343 & 112.533 & $9,5 \%$ & 361 \\
\hline Humedales Ramsar & 711.334 & 326.549 & $45,9 \%$ & 203 \\
\hline TOTAL & 566.641 .369 & 7.434 .204 & $13,12 \%$ & 2122 \\
\hline
\end{tabular}

Teniendo en cuenta lo anterior, es claro que actualmente se ha hecho evidente la falta de articulación en la coordinación al interior del gobierno nacional, pues no existe concordancia entre las políticas medio ambientales y las reglas para el desarrollo de la locomotora minera. Este problema no solo afecta estos sectores: quienes sufren sus efectos son los particulares e inversionistas que apuestan para desarrollar proyectos mineros en Colombia, al encontrar que la seguridad jurídica que requiere la inversión queda en entredicho por la falta de reglas claras para el desarrollo de la actividad minera.

\section{EL CONTRATO DE CONCESIÓN MINERA EN COLOMBIA}

\section{A. Definición y características}

Según el artículo 45 del Código de Minas, el contrato de concesión minera es aquel que se celebra "entre el Estado y un particular para efectuar, por cuenta y riesgo de este, los estudios, trabajos y obras de exploración de minerales de propiedad estatal que puedan encontrarse dentro de una zona determinada y para explotarlos 
en los términos y condiciones establecidos en el Código".

El contrato concede el derecho de explorar y explotar un yacimiento mineral en el área otorgada y a que el titular se haga a la propiedad de los minerales una vez extraídos. El Consejo de Estado (Sección Tercera, Sentencia del 3 de febrero de 2010) ha establecido que el derecho que otorga el contrato es un derecho que no puede calificarse como un derecho real, pues este solo lo tiene el Estado respecto del mineral in situ y en ningún caso lo transfiere. De esta manera, ha concluido que el contrato de concesión otorga un derecho patrimonial o personal oponible frente a terceros, en el que el concesionario puede perseguir el cumplimiento de los derechos que adquiere del Estado con el otorgamiento del título. Por otro lado, del contrato de concesión se desprende la actividad propiamente dicha de exploración o explotación del bien público, y da nacimiento a unas obligaciones de carácter legal.

El contrato de concesión minera se encuentra supeditado al principio de temporalidad, pues en Colombia no existen derechos a perpetuidad sobre las minas y, por consiguiente, durará el término que solicite el proponente hasta un máximo de 30 años. Según el artículo 46 del Código, durante el término de ejecución y sus prórrogas, al contrato de concesión le serán aplicables las leyes mineras vigentes al tiempo de su perfeccionamiento. Sin embargo, la ley tiene en cuenta que pueden existir normas posteriores al contrato que necesariamente deben ser aplicadas a este, como normas ambientales o de orden técnico, pero reconoce que hay otras que modifican o derogan términos, o imponen condiciones, requerimientos y trámites adicionales que no deben ser aplicadas, para garantizar la estabilidad jurídica del contrato durante toda su vigencia (Congreso de la República, 2000). Por esta razón, el artículo 352 establece que si el Código consagra beneficios de orden operativo o técnico, facilidades y eliminación de trámites e informes que resulten más favorables para los beneficiarios de un título minero, estos le serán aplicados.

Finalmente, el artículo 49 del Código cataloga el contrato de concesión minera como un contrato de adhesión, pues para su celebración no hay lugar a pre-negociar sus términos y modalidades. Según la Exposición de Motivos del Código, esto se debe a que se prestaría para generar tratamientos de desigualdad y daría margen a arbitrariedades (Congreso de la República, 2000). En consecuencia, se entiende que cada una de las cláusulas, términos y condiciones del contrato provienen de una norma legal, y que las obligaciones de carácter legal, técnico, operativo y ambiental están expresamente señaladas en el Código y en otras normas, por lo que ninguna autoridad podrá imponerle al concesionario otras obligaciones ni señalarle requisitos de fondo o forma adicionales.

\section{B. Etapas del contrato}

\section{Exploración}

De acuerdo con el artículo 78 del Código de Minas, los trabajos de exploración son aquellos 
necesarios para establecer y determinar la existencia y ubicación del mineral contratado, la geometría del depósito dentro del área de concesión, en cantidad y calidad económicamente explotables, la viabilidad técnica de extraerlos y el impacto que sobre el medio ambiente y el entorno social puedan causar estos trabajos y obras.

La exploración técnica ${ }^{1}$ del área concesionada deberá hacerse dentro de los tres años siguientes a la fecha de inscripción del contrato (Ley 685 de 2001, art. 71), pero el concesionario podrá señalar en el contrato un periodo de exploración menor si así lo considera. El artículo 74 del Código, modificado por el artículo 5 de la Ley 1382 de 2010, dispone que si resulta necesaria una prórroga superior a dos años, el concesionario "podrá continuar las exploraciones, solicitando prórrogas adicionales de 2 años cada una, hasta completar un término total de 11 años".

De conformidad con el artículo 84 del Código, "como resultado de los estudios y trabajos de exploración, el concesionario, antes del vencimiento definitivo de este periodo, presentará para la aprobación de la autoridad concedente o el auditor, el Programa de Trabajos y Obras (PTO) que se anexará al contrato como parte de las obligaciones". El PTO suministra la base técnica, logística, económica y comercial para tomar la decisión de invertir y desarrollar un proyecto minero. Este deberá ser presentado

1 Los estudios, trabajos y obras de exploración están encaminados a calcular técnicamente las reservas del mineral, la ubicación y características de los depósitos o yacimientos, la elaboración detallada del plan minero por ejecutarse, los medios y métodos de explotación y la escala y posible duración de la producción esperada (Ley 685 de 2001, art. 80)
30 días antes de finalizar la etapa de exploración y la autoridad concedente lo aprobará o le formulará objeciones dentro de los 30 días siguientes. Así mismo, de conformidad con el artículo 85 del Código, simultáneamente con la presentación del PTo, el concesionario deberá presentar un estudio que demuestre la factibilidad ambiental de dicho programa, que deberá incluir los requisitos contenidos en el artículo 204 del Código.

Ahora bien, la etapa de exploración no requiere para su realización el otorgamiento de una licencia ambiental, a menos que los trabajos impliquen la construcción de vías que deban tramitar licencia ambiental (Ley 685 de 2001, art. 205). Se ha considerado que no es necesaria la licencia en esta etapa del proceso pues estos trabajos y obras no generan un impacto considerable sobre el medio ambiente. Sin embargo, el concesionario deberá realizar la exploración siguiendo las disposiciones contenidas en las guías minero ambientales expedidas por el Ministerio de Minas y Energía en conjunto con el Ministerio de Medio Ambiente ${ }^{2}$, y los términos de referencia del contrato. Así mismo, el concesionario deberá intentar minimizar los efectos nocivos de las actividades de exploración sobre el medio ambiente, y cuando en desarrollo de los trabajos de exploración se requiera usar en forma ocasional o transitoria recursos renovables de la zona explorada, deberá solicitar a la

2 Las guías minero-ambientales son solamente "un instrumento de referencia para el manejo ambiental y por lo tanto, el concesionario deberá ajustarla a las características y condiciones específicas del área solicitada" (Ministerio de Minas y Energía \& Ministerio de Medio ambiente, 2002, p. 21). 
autoridad competente el correspondiente permiso, autorización o concesión para el aprovechamiento de estos recursos.

La Ley 685 de 2001 no es clara en cuanto a la fecha de terminación del periodo de exploración. Si bien existen varias teorías y posibilidades que pueden ser sustentadas legalmente, según la doctora Margarita Ricaurte (2010, p. 150), esta fase del contrato termina con la radicación por parte del concesionario del PTO "puesto que esta fecha puede ocurrir desde el día 1 hasta el último. Así, una vez presentado el PTo, el contrato pasará a la etapa siguiente, aunque esta no pueda ser ejecutada materialmente hasta tanto no reúna todos los requisitos".

\section{Construcción y montaje}

Las obras de construcción, según el artículo 91 del Código de 2001, son aquellas "obras civiles de infraestructura que resultan indispensables para el funcionamiento normal de las labores de apoyo y administración de la empresa minera y las que se requieran para ejercitar las servidumbres de cualquier clase a que tiene derecho el minero". Por su parte, de conformidad con el artículo 90, el montaje minero "consiste en la preparación de los frentes mineros y en la instalación de las obras, servicios, equipos y maquinaria fija, necesarios para iniciar y adelantar la extracción o captación de los minerales, su acopio, su transporte interno y su beneficio".

El periodo de construcción y montaje, que tiene una duración de tres años, comienza una vez termina la fase de exploración, es decir, que según la teoría acogida, comienza una vez sean presentados el Programa de Trabajos y Obras y el Estudio de Impacto Ambiental.

Las construcciones, instalaciones y montajes que se lleven a cabo en esta etapa deberán tener las características, dimensiones y calidades señaladas en el Pтo, sin perjuicio de que el concesionario pueda efectuar las modificaciones que sean necesarias durante su ejecución (Ley 685 de 2001, art. 89), manteniendo al tanto a las autoridades mineras y ambientales de esos cambios y adiciones introducidos. En el acto de aprobación del PTo, la autoridad minera autorizará expresamente la iniciación de los trabajos de explotación, pero solamente si se ha acreditado la obtención de la respectiva licencia ambiental (Ley 685 de 2001, art. 281).

Así las cosas, se hace evidente entonces que la obligación principal para poder dar inicio a esta etapa es la de acreditar que se cuenta con la licencia ambiental. Si bien el numeral 2 del artículo 8 del Decreto 2820 de 2010 establece que solo es necesaria la obtención de la licencia ambiental para la etapa de explotación, el artículo 205 del Código de Minas, modificado por el artículo 13 de la Ley 1382, determina que la licencia ambiental se hace necesaria para la etapa de construcción y montaje. Teniendo en cuenta que el artículo 3 del Código de 2001 instituye que la legislación minera es de aplicación preferente, es claro entonces que según lo dispuesto en el Código, la etapa de construcción y montaje sí requiere de licencia ambiental previa para su inicio. Por lo tanto, si una vez iniciada la etapa de construcción y montaje no ha sido aprobada la licencia ambiental por la autoridad ambiental competente, no podrán eje- 
cutarse los trabajos y obras correspondientes a esta etapa hasta que la autoridad ambiental emita la decisión aprobatoria.

\section{Explotación}

Según el artículo 95 del Código de Minas, "la explotación es el conjunto de operaciones que tienen por objeto la extracción o captación de los minerales yacentes en el suelo o subsuelo del área de la concesión"3.

El periodo de explotación comercial de un contrato de concesión inicia formalmente al vencimiento del periodo de construcción y montaje, incluyendo sus prórrogas (Ley 685 de 2001, art. 96). El tiempo máximo de esta fase, según el artículo 73 del Código, será "el tiempo de la concesión, descontando los períodos de exploración, construcción y montaje y sus respectivas prórrogas".

Ahora bien, una de las obligaciones que tiene el concesionario, una vez terminado el periodo de construcción y montaje, es dar aviso por escrito de ello a las autoridades mineras y ambientales, y a partir de ese momento se entiende que el periodo de explotación se ha iniciado formalmente.

Así mismo, es claro que de conformidad con la legislación ambiental y minera, los beneficia-

3 Si bien el mismo artículo señala que hacen parte de esta etapa su acopio, beneficio, cierre y abandono de los montajes y de la infraestructura, la Corte Constitucional (Sentencia C-800 de 2008) señaló que "la etapa de explotación termina cuando el recurso es colocado en boca o borde de mina, y que las etapas posteriores ya no son explotación del recurso". rios de un contrato de concesión no pueden adelantar trabajos de explotación minera sin la correspondiente licencia, toda vez que esta constituye uno de los requisitos indispensables para el inicio de los trabajos y obras de explotación.

\section{ZONAS EXCLUIBLES DE LA MINERÍA}

\section{A. Fundamentos para la existencia de las zonas excluibles de la minería}

La industria minera produce impactos positivos en los sectores económico y social, pues genera progreso y prosperidad en las regiones donde se desarrolla, y contribuye a aumentar el producto interno bruto de la Nación (AngloGold Ashanti Colombia, s.f.). Sin embargo, sin duda alguna también produce cambios significativos en el medio ambiente. Según un estudio elaborado por el Environmental Law Institute (1995), la actividad minera puede alterar el paisaje, cambiar la estructura del subsuelo y dispersar contaminantes hacia el aire, agua y suelo. Así mismo, puede causar contaminación auditiva por el ruido de las explosiones y ocasionar destrucción de los hábitats, pérdida de la productividad de la tierra y deterioro visual del paisaje, entre muchos otros impactos.

Resulta necesario entonces equilibrar el grave impacto ambiental de la actividad minera con la protección de la biodiversidad y el derecho a un medio ambiente sano, para que ambos sean compatibles y ninguno se deba ver perjudicado. 
Teniendo en cuenta la importancia de lograr un equilibrio entre la actividad económica y lo ambiental, algunas normas contenidas en la legislación minera limitan o restringen la posibilidad de realizar actividades mineras y otorgar contratos de concesión en áreas definidas como de protección ambiental. Luego de la importancia que cobró el medio ambiente con la Constitución de 1991, la Ley 685 de 2001, que derogó el Código de Minas de 1988, define como uno de sus objetivos el de fomentar la exploración técnica y la explotación de los recursos mineros, y establece que su aprovechamiento se debe realizar "en forma armónica con los principios y normas de explotación racional de los recursos naturales no renovables y del ambiente, así como dentro de un concepto integral de desarrollo sostenible".

El legislador encontró entonces la necesidad de

sustraer de la actividad minera ciertas zonas y lugares que por sus características especiales, su afectación a ciertos servicios o por ser inherentes a ciertos valores y bienes que podrían destruirse o deteriorarse con las obras o labores extractivas, deben conservarse fuera de estas actividades en forma absoluta. (Congreso de la República, 2000).

Así, en la Ley 685 se previeron zonas excluibles de la minería, donde no pueden ejecutarse trabajos y obras de exploración y explotación sobre áreas que hayan sido declaradas y delimitadas como áreas protegidas. De la misma manera, la Ley previó además zonas de minería restringida en las cuales sí pueden efectuarse las actividades mencionadas, pero con las limitaciones que la misma disposición enumera.

\section{B. El régimen legal de las zonas exclui- bles de la minería}

A partir de la importancia de la relación entre el medio ambiente y la actividad minera, y de acuerdo con la dimensión ecológica del ordenamiento fundamental, el legislador previó “algunas zonas que por ser de especial valor para la conservación ecológica y ambiental debían excluirse totalmente de la minería" (Consejo de Estado, Sección Tercera, Sentencia del 23 de junio de 2010). El artículo 34 del Código de Minas es la disposición que desarrolla lo relativo a estas áreas denominadas "zonas excluibles de la minería".

Ahora bien, el artículo 3 de la Ley 1382 de 2010 modificó el régimen de zonas excluibles de la minería contenido en el artículo 34 del Código de 2001. Si bien la Corte Constitucional declaró inexequible condicionalmente la Ley de 2010 por medio de la Sentencia C-366 de $2011^{4}$, en esta misma estableció que es necesario que la Ley y específicamente todas las disposiciones incluidas en ella relativas al medio ambiente continúen vigentes hasta que el Congreso tramite el nuevo Código. Por esta razón, resulta necesario entonces hacer un análisis de lo que

4

Varias de las disposiciones contenidas en la Ley 1382 de 2010 estaban destinadas a aumentar los estándares y exigencias frente al impacto ambiental de la actividad minera. Por esta razón, la Corte Constitucional (Sentencia C-366 de 2011) consideró que con el retiro inmediato de la ley desaparecerían normas esenciales para garantizar la preservación de ciertas zonas de impacto ambiental y de las consecuencias nocivas que trae la actividad minera. Así las cosas, y para evitar un vacío normativo sobre la materia ambiental en el ámbito minero y a la vez proteger el derecho de las comunidades étnicas a ser consultadas sobre las medidas legislativas, la Corte decidió diferir los efectos de inconstitucionalidad de la Ley por un término de dos años y le impuso la obligación al Gobierno y al Congreso de tramitar una nueva Reforma al Código de Minas de 2001 dentro del mismo término. 
prevé el artículo 3 de la Ley 1382 de 2010, que reformó el artículo 34 del Código de 2001.

\section{Prohibición}

El inciso primero del artículo 3 de la Ley 1382 contiene una prescripción de carácter prohibitivo (Consejo de Estado, Sección Tercera, Sentencia del 23 de junio de 2010) que dispone la imposibilidad de llevar a cabo trabajos y obras de exploración y explotación minera en las zonas excluibles de la minería. La norma establece que "no podrán ejecutarse trabajos y obras de exploración y explotación minera en zonas declaradas y delimitadas conforme a la normatividad vigente como de protección y desarrollo de los recursos naturales renovables o del ambiente".

Así, es claro entonces que esta disposición concuerda con los postulados de la Constitución sobre la protección del medio ambiente y de los recursos naturales, en el entendido de que resulta necesario proteger ciertas zonas de valor ecológico, de actividades del ser humano que puedan llegar a deteriorar sus recursos.

Sin embargo, la prohibición contenida en el inciso no opera de plano pues este impone una condición para su aplicación: exige que las zonas en cuestión sean delimitadas y declaradas conforme a la normatividad vigente como de protección y desarrollo de los recursos naturales renovables o del ambiente ${ }^{5}$. La autoridad minera ha

5 Según la Corte Constitucional (Sentencia C-443 de 2009), estas zonas corresponden a las áreas de especial importancia ecológica aludidas por el artículo 79 constitucional, "respecto de las cuales se predica un deber de protección estatal por integrar el patrimonio ambiental de la Nación, motivo por el cual se justifica su exclusión de la exploración y la explotación minera". dicho que es necesario fijar los límites del área por medio de criterios técnicos para cumplir con el requisito de la delimitación y, además, se hace indispensable la expedición de un acto administrativo motivado por parte de la autoridad ambiental competente para la declaración. Sin embargo, en la práctica la mayoría de los actos que declaran un área como zona de protección también contienen su alinderación.

\section{2. Áreas de exclusión y reglas para su delimitación y declaración}

El inciso segundo del artículo 3 de la Ley 1382 contiene una lista no taxativa ${ }^{6}$ de las áreas de exclusión y dispone que estas serán

las que han sido constituidas y las que se constituyan conforme a las disposiciones vigentes, como áreas que integran el sistema de parques nacionales naturales, parques naturales de carácter regional, zonas de reserva forestal protectora y demás zonas de reserva forestal, ecosistemas de páramo y los humedales designados dentro de la lista de importancia internacional de la Convención Ramsar. ${ }^{7}$

Si bien el artículo 3 aludido solo menciona la prohibición en los humedales incluidos en la Lista Ramsar, la Ley 1450 de 2011, por medio de la cual se expidió el Plan Nacional de Desarro-

6 Esta lista es simplemente enunciativa pues la Corte Constitucional ha dicho que "además de las zonas de exclusión previstas en esta Ley, pueden existir otras, ya declaradas con anterioridad o que se declaren en el futuro por la autoridad ambiental" (Sentencia C-339 de 2002).

7 Es pertinente aclarar que el Código de 2001 solamente contemplaba como zonas de exclusión los parques naturales nacionales, los parques naturales de carácter regional y las zonas de reserva forestal. Las demás áreas fueron incluidas en la reforma introducida por la Ley 1382 de 2010. 
Ilo para el periodo 2010 - 2014, establece que "en los ecosistemas de humedales se podrán restringir parcial o totalmente las actividades agropecuarias, de exploración de alto impacto y explotación de hidrocarburos y minerales con base en estudios técnicos, económicos, sociales y ambientales adoptados por el Ministerio de Medio Ambiente". Así, la prohibición se hace extensiva a todos los humedales, siempre y cuando se fundamente en estudios que demuestren la incompatibilidad de las actividades con el ecosistema.

Ahora bien, según el Consejo de Estado (Sección Tercera, Sentencia del 23 de junio de 2010), el inciso segundo del artículo 3 contiene una prescripción atributiva de competencia, pues dispone que "estas zonas para producir estos efectos, deberán ser delimitadas geográficamente por la autoridad ambiental con base en estudios técnicos, sociales y ambientales". Así como el inciso primero, esta disposición también requiere de ciertas condiciones para ser aplicada.

En primer lugar es necesario que la delimitación geográfica se adelante con base en estudios técnicos, sociales y ambientales. Para ello, el Ministerio de Medio Ambiente elaboró una Guía donde establece que es indispensable consultar, como fuentes de información oficial, a diferentes entidades vinculadas y adscritas al Ministerio así como otras autoridades especializadas en ciertos temas relativos a los recursos naturales ${ }^{8}$.

8 Entre otras, el Instituto Geográfico Agustín Codazzi, para cartografía básica; el Servicio Geológico Nacional, para información geológica; el IDEAM, para información hidrológica; el INVEMAR, para información sobre la calidad del agua; y la Unidad Administrativa Especial de Parques Naturales Nacionales, para información sobre fauna y flora.
Como segundo requisito para la delimitación de una zona excluible de la minería, el parágrafo tercero del artículo 3 de la Ley 1382 dispone que es necesario un concepto previo no vinculante del Ministerio de Minas y Energía, es decir, que los estudios que presenta la autoridad ambiental se llevan a cabo con la colaboración y opinión del Ministerio de Minas, pues se hace necesaria una tarea de coordinación para garantizar el desarrollo sostenible del área y mantener el equilibrio entre el ámbito económico y el ambiental (Consejo de Estado, Sección Tercera, Sentencia del 23 de junio de 2010).

Ahora bien, teniendo en cuenta que la reforma sumó como zona excluible de la minería los ecosistemas de páramo, el artículo dispone un requisito adicional para la delimitación de estos. Al respecto, establece en su inciso tercero que estos deberán ser identificados de conformidad con la información cartográfica proporcionada por el Instituto de Investigación de Recursos Biológicos Alexander von Humboldt, y a partir de esa información las autoridades ambientales deberán delimitar las áreas. Sin embargo, el alcance legal de la exclusión de estos ecosistemas ha sido interpretado de diferentes formas. Para las autoridades ambientales, la sola promulgación de la Ley 1382

es suficiente para entender que ha quedado terminantemente prohibido el desarrollo de la minería en las zonas de páramo que han sido identificadas por el Instituto Alexander Von Humboldt a través del Atlas de Páramos y no se requiere de otros actos de la autoridad ambiental para prohibir la minería en los páramos" (Álvarez, 2011, p. 174). 
Por su parte, autoridades como el propio Instituto Humboldt (18 de marzo de 2010) y la Procuraduría Delegada para Asuntos Ambientales y Agrarios (22 de diciembre de 2010) sostienen que la función a cargo del Instituto es solamente la de proporcionar la información cartográfica existente para la identificación de los páramos y que no compete a esta entidad ni hacer la delimitación de páramos ni la realización de estudios para este efecto. Con la información disponible y basada en los estudios técnicos necesarios, la autoridad ambiental es quien tiene la potestad y obligación de delimitar, caracterizar, zonificar y ordenar las zonas de páramo, conforme a las resoluciones 769 de 2001 y 839 de 2003 del Ministerio del Medio Ambiente. De esta manera, existe la posibilidad de que geológicamente una zona reúna todas las características para ser considerada un páramo pero no sea reconocida como una zona excluible. Teniendo en cuenta que la norma establece específicamente que para que la zona sea considerada como excluible esta debe estar delimitada, se podría decir entonces que las áreas que no estén delimitadas y declaradas no son consideradas jurídicamente como páramos y, por consiguiente, no sería aplicable la exclusión contemplada en la reforma al Código de Minas. ${ }^{9}$

Sin embargo, para evitar este problema, que ha sido aprovechado por los concesionarios mineros para continuar con sus proyectos, la Ley

9 La Procuraduria Delegada para Asuntos Ambientales y Agrarios (22 de diciembre de 2010) considera que "las autoridades ambientales deben abstenerse de otorgar o negar las licencias ambientales que se encuentren en trámite o aquellas que en el futuro se soliciten, hasta tanto se delimiten las áreas de páramos que deberán ser excluidas de la minería".
1450 de 2011 estableció en su artículo 22 que para los efectos de la prohibición de desarrollar actividades mineras en los páramos, "se considera como referencia mínima la cartografía contenida en el Atlas de Páramos de Colombia del Instituto de Investigación Alexander von Humboldt, hasta tanto se cuente con cartografía a escala más detallada". Es claro, entonces, que simplemente con esta información existente las autoridades ambientales ya pueden comenzar a delimitar las zonas de páramo para que empiecen a surtir los efectos de la exclusión de la minería.

\section{Explotación excepcional}

Según el Decreto 2372 de 2010, existe la posibilidad de sustraer total o parcialmente un área protegida cuando hayan razones de utilidad pública e interés social para hacerlo, o cuando quiera que se proyecte desarrollar actividades no permitidas en la zona. Teniendo en cuenta que la minería es una actividad de utilidad pública por expresa disposición de la ley, el mismo Código de Minas consagra, en el artículo bajo estudio, la posibilidad de permitir la sustracción de áreas de protección para llevar a cabo proyectos mineros.

El cuarto inciso del artículo 3 de la Ley 1382 establece que "las áreas de reserva forestal creadas por la Ley $2^{\text {da }}$ de 1959 y las áreas de reserva forestales regionales, podrán ser sustraídas por la autoridad ambiental competente". De la lectura de esta norma se puede desprender con claridad que las zonas de reserva forestal protectora y demás zonas excluibles de la minería 
contempladas en el artículo no son susceptibles de sustracción. ${ }^{10}$

Esta disposición, según el análisis realizado por el Consejo de Estado (Sección Tercera, Sentencia del 23 de junio de 2010), contiene una prescripción permisiva excepcional que se concreta al disponer que, previo el cumplimiento de ciertos requisitos, la autoridad minera está facultada para autorizar actividades mineras en dichas zonas.

El inciso cuarto establece, como uno de los requisitos para la explotación excepcional, que la autoridad minera, al otorgar el contrato de concesión a su titular, "deberá informarle que se encuentra en el área de reserva forestal y por ende no podrá iniciar las actividades mineras hasta tanto la autoridad ambiental haya sustraído el área". De esta disposición se concluye, entonces, que un título minero puede ser otorgado en un área de reserva forestal que pueda ser sustraída posteriormente, pero mientras la autoridad ambiental no perfeccione la sustracción, el titular de la concesión no puede iniciar ni siquiera los trabajos de exploración. ${ }^{11}$ Según la Resolución 0198 de 2011 expedida por el Ministerio de Medio Ambiente, para llevar a cabo los trabajos inherentes a la exploración minera es necesario facilitar la sustracción temporal del área y, al finalizar esta etapa, la reserva forestal recobra su condición, por lo que el concesiona-

10 La Ley 1450 de 2011 reitera en su artículo 204 que en las áreas de reserva forestal protectoras no se podrán desarrollar actividades mineras ni se podrán sustraer para ese fin.

11 Es viable iniciar de manera simultánea los trámites para la obtención de la licencia ambiental y para el levantamiento de la reserva forestal, pero la licencia solo será otorgada cuando la sustracción haya sido aprobada (Construdata, 2011). rio deberá solicitar a la autoridad ambiental la sustracción definitiva para poder iniciar las fases de construcción y montaje y explotación.

Ahora bien, el mismo inciso cuarto dispone que, como requisito para la explotación excepcional, el concesionario minero tenga la carga de aportar "los estudios que demuestren la adecuada coexistencia de las actividades mineras con los objetivos del área forestal". En igual sentido, el inciso quinto del artículo bajo análisis establece que la autoridad minera, en concordancia con las determinaciones ambientales establecidas, "deberá fijar las condiciones para que las actividades de exploración y explotación propuestas se desarrollen en forma restringida o solo por determinados métodos y sistemas, de tal forma que no afecten los objetivos del área de reserva forestal no sustraída"12.

\section{Régimen de transición}

Como última medida, el artículo 3 de la Ley 1382 de 2010 adiciona un precepto completamente nuevo que no se encontraba en el Código de 2011. El parágrafo primero del artículo 3 prescribe que

en caso de que a la entrada en vigencia de la presente ley se adelanten actividades de construcción, montaje o explotación minera con título minero y licencia ambiental o su equivalente en áreas que anteriormente no estaban excluidas, se respetarán tales actividades has-

12 Al respecto, el Ministerio de Minas y Energía (14 de febrero de 2008) ha resaltado la importancia de la compatibilidad entre la minería y los objetivos del área, pues se debe tener en cuenta que "corresponde a un área que aunque esté sustraída para efectos de minería, su manejo debe hacerse teniendo en cuenta que en conjunto hace parte de un área de protección ambiental". 
ta su vencimiento, pero estos títulos no tendrán opción de prórroga.

Esta disposición constituye el eje central para la problemática planteada en el presente trabajo, pues contiene un régimen de transición en el cual se establece qué ocurre con los títulos mineros que fueron otorgados con anterioridad a la declaratoria de una zona excluible de la minería. Sin embargo, el régimen de transición previsto es incompleto, pues solamente dispone qué sucede con los títulos que cuenten con licencia ambiental o su equivalente, y que se encuentren en las etapas de construcción y montaje y explotación, y no contiene ninguna reglamentación sobre qué ocurre con los títulos mineros que se encuentren en otras etapas y no cumplan con esos requisitos.

\section{EFECTOS DE LA DECLARATORIA DE UNA ZONA EXCLUIBLE DE LA MINERÍA SOBRE LOS TÍTULOS MINEROS PRE- EXISTENTES EN LA ZONA}

Teniendo en cuenta que ni la Ley minera ni la reglamentación ambiental prevén soluciones para el problema de investigación planteado, en la actualidad ha habido numerosos casos en los que titulares mineros que ya han venido desarrollando sus actividades legalmente han tenido que frenarlas debido a la declaratoria de una zona excluible sobre el área que les fue concesionada.

Uno de esos casos, que fue objeto de debates entre ambientalistas, inversionistas, la sociedad civil, periodistas y el Gobierno, es el del Pro- yecto de Angostura de la compañía canadiense Greystar Resources. Durante las últimas dos décadas, esta empresa adquirió varios títulos mineros que fueron otorgados por la autoridad minera en la década de los 90, en los departamentos de Santander y Norte de Santander (Pardo, s.f.). La compañía canadiense ha adelantado labores de exploración desde 1994 en el área y para acogerse al régimen de la Ley 685 de 2001, en febrero de 2007 Greystar suscribió un contrato de concesión que además integró todos los títulos (Rodado, 2011). La compañía presentó el Estudio de Impacto Ambiental y solicitó la licencia ambiental global para el Proyecto de Angostura, el 23 de diciembre de 2009. Sin embargo, mientras la licencia ambiental se encontraba en trámite, el 9 de febrero de 2010 se sancionó la Ley 1382, que incluyó dentro de las zonas excluibles de la minería los páramos. Según la revista Dinero (2010), entre el 52.9 y el 54 por ciento del área requerida para el desarrollo del proyecto está situada dentro del páramo de Santurbán. Por esta razón, la autoridad ambiental exigió a Greystar que presentara un nuevo Estudio de Impacto Ambiental pues consideró que el proyecto de explotación planteado no era viable. La compañía desistió de su solicitud de licencia ambiental y prefirió retirar el proyecto, pero decidió conservar el título para poder presentar un proyecto ambientalmente viable en un futuro (Flores, 2011). La inversión de Greystar para desarrollar el proyecto fue alta: la suma de dinero invertida alcanzó los 135 millones de dólares entre obras y trabajos de exploración, adquisición de tierras, estudios técnicos y ambientales e impuestos (Reyes, 2010). 
El caso de Santurbán es solo uno de los que han sonado ante la opinión pública respecto de títulos mineros superpuestos con áreas protegidas, que ha ocurrido no porque los aspirantes a obtener contratos de concesión hayan solicitado ingresar a zonas excluibles, sino porque estas zonas han sido declaradas como tales con posterioridad al otorgamiento del título minero sin que se haya considerado ningún periodo de transición (“ANDI pide legislación...”, 2011). Así, surge entonces una controversia entre la protección del medio ambiente y los derechos de los particulares, derivados de un título minero otorgado de acuerdo con la ley, pues con la declaratoria de un área excluible de la minería se pretende garantizar el desarrollo sostenible y la preservación del medio ambiente, pero al mismo tiempo se desconocen los derechos de un titular minero al no poder este desarrollar las actividades de minería en la zona que antes no estaba protegida. Así mismo, este tipo de situaciones crean un panorama adverso para el futuro de la inversión en Colombia, pues otras compañías nunca llegarían a invertir en proyectos mineros ante el miedo y la desprotección que genera esa falta de seguridad jurídica.

Por esta razón, es imperioso encontrar una solución a esta problemática que ha venido creciendo y se ha hecho cada vez más frecuente. Teniendo en cuenta que, como fue mencionado anteriormente, no existe ningún tipo de solución en las leyes que regulan la materia, es necesario entonces hacer un análisis de la situación utilizando teorías constitucionales y principios de derecho administrativo que, aplicados al caso concreto, pueden llegar a acercarse a una posible solución a esta tensión.

\section{A. Principios}

\section{Derechos adquiridos y meras expectativas}

El principal argumento de los inversionistas y titulares mineros cuando es declarada una zona excluible de la minería sobre un área con un título minero otorgado anteriormente es que, con ocasión de esta nueva situación o norma modificatoria, los derechos adquiridos derivados de su título se ven afectados ante la imposibilidad de poder desarrollar sus actividades en la zona. Si bien esto podría llegar a ser cierto, resulta necesario hacer un análisis de lo que se ha considerado como un derecho adquirido, pues no siempre un titular minero cuenta con este.

El concepto de derecho adquirido ha sido definido por varios tratadistas como un derecho que ha entrado en el patrimonio de una persona, en virtud de las leyes vigentes en el tiempo en que el hecho hubiere tenido lugar. Según el doctrinante italiano Pascuale Fiore (1927, p. 234), un derecho adquirido es un derecho que se debe tener por nacido "por haberse íntegramente verificado todas las circunstancias del acto idóneo, según la ley en vigor, para atribuir dicho derecho consumado pero que no fue ejecutado enteramente antes de haber comenzado a entrar en vigor la ley nueva".

La Constitución Política de Colombia de 1991, en su artículo 58 consagra la protección de los derechos adquiridos con arreglo a las leyes civiles, los cuales no pueden ser desconocidos ni vulnerados por leyes posteriores. Sin embargo, 
no desarrolla el concepto de derecho adquirido, por lo que la jurisprudencia colombiana ha sido abundante en este tema.

La Corte Suprema de Justicia (Sala de Casación Civil, Sentencia del 17 de marzo de 1977) entiende como derechos adquiridos "aquellas situaciones individuales y subjetivas que se han creado y definido bajo el imperio de una ley, y que por lo mismo han creado a favor de sus titulares un cierto derecho que debe ser respetado (...) mediante la prohibición de que leyes posteriores pretendan regularlos nuevamente".

De otro lado, el Consejo de Estado (Sección Tercera, Sentencia del 12 de agosto de 2002) ha establecido que los derechos adquiridos

se originan en la consolidación de una situación originada bajo el amparo de una ley que la regula, vale decir que si se concretaron los supuestos normativos por haberse verificado su cumplimiento independientemente de que la consecuencia que se deriva de ello se materialice posteriormente, aquellos ingresan definitivamente al patrimonio del titular y por ende quien los otorgó no los puede quitar sin vulnerarlos.

Partiendo del desarrollo jurisprudencial mencionado anteriormente, la Corte Constitucional (Sentencia C-168 de 1995) ha concluido que los derechos adquiridos se reconocen por ser derechos que son (i) subjetivos, (ii) concretos y consolidados, (iii) cumplen con los requisitos de ley, (iv) se pueden exigir plenamente, (v) se encuentran jurídicamente garantizados, (vi) se incorporan al patrimonio de la persona, (vii) son intangibles y en consecuencia el legislador al expedir una nueva ley no los puede lesionar o desconocer.

Ahora bien, en contraposición a los derechos adquiridos, existen situaciones que constituyen simplemente expectativas legítimas que, según Fiore (1927, p. 241), no tienen la misma eficacia y protección jurídica de la que gozan los derechos adquiridos pues no constituyen derecho contra una ley nueva que las anule o afecte. Estas, según la Corte Constitucional (Sentencia C-781 de 2003), se caracterizan

por no haber cumplido con los presupuestos legales exigidos para la consolidación del derecho, y aunque puedan llegar a perfeccionarse en el futuro, tan solo son probabilidades $\mathrm{y} / \mathrm{o}$ esperanzas que no constituyen derechos subjetivos consolidados y pueden ser modificadas legítimamente por el legislador con el fin de cumplir con objetivos constitucionales o motivos de interés público.

Es claro que la vigencia de la ley en el tiempo juega un papel fundamental en la distinción entre los derechos adquiridos y las meras expectativas: mientras los primeros no pueden ser desconocidos por las leyes posteriores, las segundas no gozan de esa protección. Según la Corte Constitucional (Sentencia C-478 de 1998), la distinción se relaciona entonces con la prohibición de la retroactividad, pues "en principio una norma posterior no puede desconocer situaciones jurídicas consolidadas durante la vigencia de una regulación anterior, pero en cambio la ley puede modificar discrecionalmente las meras probabilidades o esperanzas que se tienen de obtener algún día un derecho. 


\section{Confianza legítima}

El principio de la confianza legítima, en Colombia, tiene sus orígenes en la jurisprudencia de las altas Cortes pero hasta el momento no ha sido recogido por ninguna norma en específico. Sin embargo, se puede deducir que este principio se deriva del principio de buena fe, consagrado en el artículo 83 de la Constitución política; del principio de seguridad jurídica consagrado en los artículos 1 y 4 constitucionales y de la prevalencia del interés general sobre el particular (Viana, 2007, p. 42). Así mismo, es un principio que tiene relación clara y directa con los conceptos de derechos adquiridos y meras expectativas, analizados previamente.

Según el profesor Felipe de Vivero (2004, p. 123), la confianza legítima

se explica en la necesidad de proteger situaciones que se encuentran a mitad de camino entre los conceptos de derechos adquiridos y meras expectativas, y obedece a la necesidad de amparar situaciones a partir de las cuales jamás se podría consolidar un derecho porque pueden llegar incluso a calificarse como ilegales pero que merecen protección del Estado en razón a la actuación de buena fe de quien se encuentra en esta situación.

De esta manera, el principio de confianza legítima surge para proteger al administrado frente a cambios bruscos e intempestivos efectuados por las autoridades.

Según la Corte Constitucional (Sentencia C-478 de 1998), este principio existe para conciliar los casos en los que la administración, en su condi- ción de autoridad, ha creado expectativas favorables a los administrados y de forma abrupta cambia esas condiciones. Así mismo, ha dicho que la confianza legítima se trata de

situaciones en las cuales el administrado no tiene realmente un derecho adquirido, pues su posición jurídica es modificable por las autoridades. Sin embargo, si la persona tiene razones objetivas para confiar en la durabilidad de la regulación, y el cambio súbito de la misma altera de manera sensible su situación, entonces el principio de confianza legítima la protege.

En esos casos, en función del principio de buena fe, el Estado deberá facilitar las condiciones y medios y proporcionar al afectado el tiempo que le permita adaptarse a la nueva situación gradualmente, sin que esto signifique ni una donación, ni reparación, ni resarcimiento ni indemnización por parte del Estado (Corte Constitucional, Sentencia T-617 de 1995).

Por su parte, la Corte Suprema de Justicia (Sala de Casación Civil, Sentencia del 25 de junio de 2009) ha señalado que la confianza legítima se traduce en la protección de las expectativas de estabilidad generadas con las actuaciones previas "ante la fundada creencia de su proyección en condiciones relativas de permanencia, coherencia y plenitud, partiendo de la premisa según la cual todo ciudadano tiene derecho a prever, disciplinar u ordenar su conducta con sujeción a las directrices normativas vigentes". Por lo tanto, el principio presupone (i) un acto susceptible de infundir confianza y crear esperanzas fundadas, (ii) una situación preexistente generatriz de una expectativa verosímil, razonable y legítima basada en la confianza que inspira la autoridad 
con su conducta sobre su mantenimiento o estabilidad y (iii) una actuación de buena fe del sujeto.

Teniendo en cuenta lo anterior, es viable decir que el principio de confianza legítima no limita que el legislador derogue una norma anterior o imponga una nueva, pues la persona no goza de un derecho adquirido sino de una mera expectativa que es una situación revocable. Si bien esta situación goza de protección pues existen razones que justificaban la confianza del administrado en que la norma que lo amparaba se seguiría manteniendo, esto no impide que el legislador, por razones de interés general, modifique las regulaciones sobre un determinado asunto (Corte Constitucional, Sentencia T-321 de 2007).

\section{Protección a la inversión extranjera}

La inversión extranjera debe hacerse bajo ciertos parámetros para que esta traiga beneficios tanto para el país de destino como para el inversor. En un contrato estatal, el Estado no es solamente la contraparte contractual del inversionista sino que, además, tiene la función de regular la actividad del inversionista extranjero (Bejarano \& Cárdenas, 2012). Por esta razón, existe una necesidad de garantizar la estabilidad jurídica para los inversionistas, y por eso en Colombia se han celebrado varios tratados bilaterales y multilaterales en materia de inversiones, como tratados de libre comercio (TLC), tratados bilaterales de inversión (твI) que incluyen capítulos sobre inversión extranjera, y acuerdos bilaterales de promoción y protección recíproca de inversiones (APPRI).
Los TBI, los capítulos de inversión de los TLC y IOS APPRI contienen generalmente protecciones para las inversiones de los nacionales de los Estados con los cuales Colombia ha celebrado estos acuerdos. Así las cosas, la forma en la que una Parte asegura las inversiones realizadas en su territorio por inversores de otra Parte, cubre, entre otros aspectos, los siguientes: (i) la garantía de que el Estado dará a la inversión un tratamiento justo y equitativo así como plena protección y seguridad, prohibiendo medidas arbitrarias o que la menoscaben; (ii) el derecho a recibir el mismo trato que los inversionistas nacionales; (iii) la garantía de que no habrá expropiación, directa o indirecta, sin la adecuada compensación y por motivos de utilidad pública únicamente; y (iv) el derecho a la libre repatriación de las utilidades que se obtengan de la inversión (Díez-Hochleitner, 2010).

Ahora bien, para la problemática que nos ocupa es pertinente hacer una breve exposición de dos de estas protecciones que se ven vulneradas, precisamente, por los cambios regulatorios de un Estado o por la imposición de una nueva condición que desconozca la situación existente y menoscabe la inversión: el trato justo y equitativo y la expropiación indirecta.

\subsection{Trato justo y equitativo}

Según varios tribunales internacionales dedicados a la resolución de conflictos relativos a los asuntos de comercio $^{13}$, la obligación de

13 Centro Internacional de Arreglo de Diferencias Relativas a Inversiones (CIADI); Comisión de las Naciones Unidas para el Derecho Mercantil Internacional (CNUDMI); Corte de Arbitraje Internacional de Londres (LCIA). 
otorgar a los inversionistas foráneos un trato justo y equitativo, acorde con el estándar mínimo de tratamiento de extranjeros, implica que las Partes Contratantes deben actuar de modo transparente y previsible para proporcionarles un trato que no afecte las expectativas básicas sobre las cuales realizaron sus inversiones. Con el fin de cumplir con las expectativas legítimas del inversionista extranjero, según el CIADI (3 de octubre de 2006) el Estado receptor de la inversión tiene la obligación de proporcionar y mantener la estabilidad de su sistema jurídico, "pues esto resulta necesario para que los inversionistas puedan planificar y calcular su inversión, y ajustarse al marco legal en el país de acogida" (Schill, 2006, p. 12).

Las expectativas legítimas pueden resultar a partir de una serie de acciones atribuibles al Estado receptor de la inversión como, por ejemplo, las disposiciones del marco normativo general o declaraciones hechas por el mismo Estado y que fueron tenidas en cuenta por el inversionista (cnudmi, 3 de septiembre de 2001, párr. 611). De esta manera, el estándar de trato justo y equitativo protege a los inversionistas extranjeros de cambios abruptos en los marcos regulatorios y contractuales aplicables y, para poder determinar que el Estado ha actuado en violación de esta obligación, no es necesario encontrar que dicho Estado ha actuado de mala fe (CIADI, 3 de octubre de 2006, párr. 129).

Ahora bien, respecto al caso que nos ocupa, el CIADI ha establecido que conductas como la modificación radical de un marco regulatorio, contraria a los términos de las licencias aplicables (12 de mayo de 2005, párr. 274), así como el no otorgamiento de permisos pese a conductas previas que autorizaban la realización de la inversión (30 de agosto de 2000, párr. 105) constituyen conductas o medidas violatorias al estándar de trato justo y equitativo.

\subsection{Expropiación indirecta}

En el ámbito del derecho internacional de inversiones, una expropiación indirecta es una figura que se asimila al concepto tradicional de la expropiación, pero se da en el caso en el que el inversionista conserva el título legal de la propiedad pero ve limitados sus derechos de uso de la propiedad como consecuencia de una interferencia del Estado (Páez, 2009, p. 30), que puede producirse cuando toma medidas ${ }^{14}$ relativas a la aplicación de regulaciones del medio ambiente, la salud, la moral, la cultura, la seguridad o la economía de un país.

Para poder determinar si una medida equivalente a la expropiación ha tenido lugar, se debe tener en cuenta el efecto de la medida sobre el beneficio económico, el valor y el control de la inversión, y no la intención o propósito del Estado (Dolzer \& Shreuer, 2008, p. 101). Bajo estas directrices, el CIADI (30 de agosto de 2000, párr. 103) ha sostenido que una expropiación indirecta es aquella medida que, a pesar de no interferir con el título de propiedad del inversionista, interfiere con el uso de su propiedad en tal grado que lo priva totalmente, o en gran parte, de su uso y de los beneficios económicos que

14 Los actos o medidas de la administración del Estado se entienden como "decisiones formales que emitan sus órganos y que contengan declaraciones de voluntad del Poder Ejecutivo realizadas en el ejercicio de una potestad pública" (Páez, 2009, p. 15). 
podría haber esperado de su inversión. En otras palabras, los tribunales y la doctrina han establecido que una expropiación indirecta constituye una medida que efectivamente neutraliza el disfrute de la propiedad. A manera de ejemplo, en el caso Metalclad vs. México, el cIADI concluyó que el haberle negado al inversionista una licencia de construcción de un relleno sanitario después de que la obra estaba casi terminada, constituía una expropiación indirecta por cuanto el inversionista no podía operar el relleno.

La mayoría de acuerdos relativos a inversión protegen de este tipo de expropiación a los inversionistas extranjeros. Por consiguiente, el Estado puede llevar a cabo una expropiación de este tipo de manera legal, siempre y cuando ella reúna cuatro requisitos: (i) que se lleve a cabo por motivos de utilidad pública, (ii) que no haya discriminación, (iii) que haya una indemnización para el inversionista y (iv) que el proceso se lleve a cabo siguiendo un debido proceso.

\section{B. Escenarios en los que podría encon- trarse un título minero cuando se decla- ra un área excluible de la minería en la zona}

Habiendo esbozado los principios de derecho administrativo y de protección de la inversión extranjera es pertinente, ahora, hacer el análisis de la problemática planteada.

Sin embargo, conviene mencionar primero que si bien el contrato de concesión minera consagrado en el Código de Minas constituye un título único que abarca las etapas de exploración, construcción y montaje y explotación de un pro- yecto minero, cada una de estas fases, como fue desarrollado anteriormente, es independiente de la otra y cada una implica obligaciones distintas para su inicio y ejecución. Por esta razón, no se puede hacer una generalización de los efectos que tiene la declaratoria de una zona excluible de la minería sobre los títulos mineros existentes en ella, pues las soluciones y principios aplicables varían según la etapa en la que se encuentre la ejecución del título.

En este entendido, a continuación se hará el análisis de cada una de las situaciones en las que podría encontrarse un título minero cuando el área de la minería es declarada excluible, para determinar cuál de las teorías le es aplicable y, por ende, establecer cuáles son los efectos de la declaratoria de la zona excluible sobre el título minero.

\section{Título minero con licencia ambiental aprobada y que se encuentre en etapa de construcción y montaje o explotación}

Como fue mencionado de manera superficial en una sección anterior del presente trabajo, la Ley 1382 de 2010 prevé un régimen de transición respecto de los efectos de la declaratoria de una zona excluible de la minería sobre los títulos mineros preexistentes. Al respecto, el parágrafo primero del artículo 3 establece que en caso de que "se adelanten actividades de construcción, montaje o explotación minera con título minero y licencia ambiental o su equivalente en áreas que anteriormente no estaban excluidas, se respetarán tales actividades hasta su vencimiento". Así las cosas, de la lectura de esta disposi- 
ción se desprende claramente que solo los títulos mineros que cuenten con licencia ambiental debidamente otorgada y se encuentren en las etapas mencionadas pueden seguir ejecutando sus actividades.

Si bien la respuesta a esta situación es clara, vale la pena hacer un análisis desde los principios esbozados anteriormente que fundamentan esta disposición. Es pertinente volver a mencionar que, tanto la legislación ambiental como la legislación minera establecen que la obtención de la licencia ambiental constituye un requisito sine qua non para el ejercicio del derecho a construir y montar las estructuras necesarias para el proyecto y para poder llevar a cabo la explotación: el artículo 5 del Decreto 2820 de 2010 consagra que la obtención de la licencia ambiental es condición previa para el ejercicio de los derechos que surjan de los permisos, autorizaciones, concesiones y licencias que expidan otras autoridades diferentes a las ambientales, y el artículo 85 del Código de Minas establece que para poder iniciar la ejecución de las etapas de construcción, montaje y explotación es requisito la aprobación expresa del Estudio de Impacto Ambiental y la expedición de la Licencia Ambiental. Puede decirse, entonces, que el derecho para ejercer las etapas de construcción, montaje y explotación solo nace cuando la licencia ambiental ya ha sido otorgada, al ser esta un requisito indispensable, y es solamente a partir de este momento que el derecho puede ejercerse.

De esta manera, es posible decir que en este escenario, el beneficiario de un título minero cuenta con un derecho adquirido, pues ya ha cumplido con todos los requisitos que estable- ce la ley vigente al momento de su celebración para comenzar las etapas de construcción, montaje y explotación o para continuarlas en caso de que ya las haya iniciado. La licencia ambiental fue otorgada cuando no existía una zona excluible de la minería en el área bajo el contrato de concesión, lo que quiere decir entonces que el derecho a ejercer las etapas de construcción, montaje y explotación se perfeccionó de acuerdo con las condiciones legales del momento. Así mismo, el derecho ya entró en el patrimonio del concesionario minero al haberse perfeccionado y, por ello, el derecho se puede exigir plenamente.

Ahora bien, podría pensarse que de este escenario se derivan dos posibles situaciones con consecuencias distintas: una en la cual la licencia ambiental ya ha sido otorgada pero no se han iniciado los trabajos, y otra en la cual los trabajos ya se han iniciado. Sin embargo, la consecuencia sigue siendo la misma pues, retomando lo dispuesto por la Corte Constitucional, si ya se concretaron los supuestos normativos por haberse verificado su cumplimiento, el derecho se tiene como adquirido independientemente de que la consecuencia que se deriva de ello se materialice posteriormente. Teniendo en cuenta que el requisito para perfeccionar el derecho es la licencia ambiental y no el inicio de su ejecución, en una y otra situación se puede predicar el concepto de derecho adquirido y, por tanto, la situación debe respetarse en ambos casos, independientemente de si se ha iniciado o no la actividad.

Así las cosas, la ley respeta el derecho del concesionario minero que se encuentra en esta si- 
tuación. Sin embargo, al seguir con la ejecución del proyecto minero podría vulnerarse el derecho al medio ambiente y podría verse afectada la biodiversidad y los ecosistemas de la zona de protección. El título seguirá en ejecución y la zona continuará gozando de la protección ambiental, por lo que resulta necesario conciliar estas dos circunstancias ya que la ley intenta respetar tanto el derecho al medio ambiente como el derecho adquirido del titular minero. Por esta razón, si bien considero que la disposición de la ley es adecuada y tiene fundamentos legales sólidos para respetar los derechos emanados del título minero, creería que podría resultar necesario que la autoridad ambiental adelante con frecuencia labores de seguimiento a las actividades mineras en la zona, para al menos aminorar los impactos ambientales y que el concesionario minero también haga su mayor esfuerzo para hacer menos gravosos los impactos sobre el ecosistema.

\section{Título minero que ha presentado el Plan de Trabajos y Obras junto con el Es- tudio de Impacto Ambiental y su licencia ambiental se encuentra en trámite}

Ahora, es pertinente considerar la situación en la que un beneficiario de un contrato de concesión ha culminado con la etapa de exploración y, por consiguiente, ha presentado ante la autoridad tanto el Programa de Trabajos y Obras como el Estudio de Impacto Ambiental y ha solicitado ante la autoridad ambiental la licencia ambiental global. Sin embargo, durante el estudio de la información y el trámite, la autoridad ambiental declara una zona excluible de la minería que se superpone con el área de la concesión.
La Corte Constitucional (Sentencia C-033 de 2011) ha dicho que cuando se trata de propuestas y solicitudes ante autoridades y entidades del Estado, se está frente a meras expectativas porque no se ha adquirido derecho alguno al no haberse otorgado el respectivo permiso o licencia. El concesionario minero que está tramitando su licencia es apenas un solicitante y no es titular de ningún derecho, pues estos procesos y trámites confieren simplemente una posibilidad de llegar a adquirir un derecho. El hecho de que se presente una solicitud no quiere decir que se tenga un derecho, dado que el nacimiento de este depende de la decisión de la autoridad.

Así mismo, el Consejo de Estado ha establecido que en materia ambiental, las solicitudes que se encuentren en trámite sobre actos administrativos que confieren permisos, licencias, autorizaciones y similares son simplemente meras expectativas, en cuanto a que la decisión acerca del permiso no ha sido adoptada, por lo que no existe aún un derecho consolidado (Sección Primera, Sentencia del 12 de agosto de 1999). De la misma manera, ha dicho que estos trámites son provisionales y se encuentran subordinados al interés público, por lo tanto están supeditados a los cambios que se presenten en el ordenamiento jurídico respectivo.

Teniendo en cuenta esto, es claro entonces que si durante el trámite de la licencia ambiental existe un cambio en la normatividad o una declaración y delimitación por parte de la autoridad ambiental, de una zona excluible de la minería, por ser el trámite de la licencia solo una posibilidad de obtener la licencia, la ley sí puede intervenir y modificar la situación pues solo hay 
una esperanza de obtener el derecho a la licencia y, por consiguiente, el derecho a explotar es una mera expectativa.

Sin embargo, en esta situación es posible aplicar el principio de la confianza legítima, analizado previamente, pues se configuran los elementos integrantes ${ }^{15}$ propuestos por la Corte Suprema de Justicia en Sentencia del 25 de junio de 2009.

En cuanto al acto susceptible de infundir confianza y crear esperanzas fundadas, podría decirse que el beneficiario de un contrato de concesión que había venido explorando por un tiempo confió legítimamente en que, si el Estado lo dejó explorar la zona hasta el fin del periodo e incluso le permite llegar hasta el momento de presentar el PTo y la solicitud de licencia ambiental es porque le va a permitir explotar la zona una vez aprobados los requisitos. Teniendo en cuenta que el contrato de concesión es un contrato único y que las restricciones sobre las áreas excluibles de la minería aplican para todas las etapas del contrato, se puede deducir que si el Estado permite explorar una zona y presentar un Estudio de Impacto Ambiental es porque existen las condiciones ambientales para hacerlo y para en un futuro llevar a cabo la explotación.

En cuanto al segundo elemento, la situación preexistente que genera una expectativa razonable y legítima basada en la confianza que ins-

15 A saber: (i) un acto susceptible de infundir confianza y crear esperanzas fundadas, (ii) una situación preexistente generatriz de una expectativa verosímil, razonable y legítima basada en la confianza que inspira la autoridad con su conducta sobre su mantenimiento o estabilidad y (iii) una actuación de buena fe del sujeto. pira la autoridad sobre su estabilidad, resulta evidente que este lo constituye el hecho de que al momento de la celebración del contrato de concesión no existía una zona excluible de la minería y el contrato había sido celebrado entre el beneficiario y el Estado, cumpliendo con todos los requisitos necesarios previstos en la ley vigente del momento. Es claro que si un beneficiario celebra un contrato de concesión en un área libre y sin ningún tipo de restricción legal puede confiar en que esa situación se mantenga a través de la ejecución del contrato. El beneficiario ha hecho una inversión teniendo en cuenta leyes y situaciones vigentes y, por ende, el Estado ha creado expectativas favorables basadas en razones objetivas como lo son las leyes vigentes al momento de la celebración del contrato.

Ahora bien, como última medida, teniendo en cuenta que según la Corte Constitucional (Sentencia C-1149 de 2008) la buena fe se presume en las actuaciones que los particulares adelantan ante las autoridades públicas, no es necesario hacer un análisis de este tercer requisito propuesto por la Corte Suprema de Justicia.

El principio nacional de confianza legítima está directamente ligado con el principio de protección a inversionistas del trato justo y equitativo pues ambos protegen las expectativas legítimas del administrado o inversionista. De esta manera, podría decirse que teniendo en cuenta que el titular de un contrato de concesión en el escenario bajo análisis cuenta con una expectativa legítima, como fue analizado en el párrafo anterior, un cambio en las condiciones iniciales de contratación, como la delimitación de una zona excluible sobre el área de la concesión, constitu- 
ye tanto una violación al principio de confianza legítima como una vulneración al trato justo y equitativo para los inversionistas extranjeros. La vulneración de estos principios trae pérdidas al inversionista que, de buena fe, celebró un contrato bajo ciertas condiciones que eran legítimas en ese momento.

Ahora bien, la violación a la confianza legítima en el ámbito nacional no genera las mismas consecuencias que la vulneración del trato justo y equitativo previsto en los tratados de inversión. En el ámbito nacional, la vulneración a las expectativas legítimas conlleva que el Estado debe facilitar las condiciones y medios para proporcionar al afectado el tiempo que le permita adaptarse a la nueva situación gradualmente. En este caso es muy difícil que el titular minero pueda adaptarse a la nueva situación, pues la delimitación de una zona excluible implica una prohibición legal para desarrollar en ella la minería sobre la base de protegerla contra los impactos de esta actividad. Por esta razón, no existe ninguna manera de que el titular minero se ajuste a las condiciones y pueda explotar en la zona; la única forma viable sería que, una vez la autoridad ambiental delimite la zona, si existe alguna parte del área concesionada que no haga parte de la zona excluible de la minería, el Estado permita modificar el área para poder llevar a cabo actividad de explotación en ella. Por el contrario, por ser el trato justo y equitativo una obligación consagrada en tratados internacionales, su vulneración sí implica que el Estado repare o indemnice al inversionista extranjero por los perjuicios causados con la modificación de las condiciones iniciales.

\section{Título minero en etapa de exploración}

Finalmente, se plantea el escenario en el cual el título se encuentra en la etapa de exploración y es declarada en el área una zona excluible de la minería. Según el ministro de Minas, Mauricio Cárdenas Santamaría, en Colombia el contrato de concesión, que otorga en primer lugar el derecho para la exploración minera, no concede automáticamente el derecho a la explotación, pues este es un derecho condicionado a la obtención de la licencia ambiental ("Nadie quedará contento", 2011). Así mismo, el derecho a explotar también se encuentra condicionado por los resultados que arrojen los trabajos y obras de exploración, pues en esta etapa es cuando se verifica si existe el mineral contratado dentro del área de la concesión en calidad y calidad económicamente explotables y si el proyecto es viable técnica y ambientalmente. Por lo anterior, podría decirse que en cierta medida el perfeccionamiento del derecho a explotar depende de condiciones externas que podrían o no darse, por lo que es una simple posibilidad.

Cuando una zona excluible se delimita en esta etapa, si bien ya se ha comenzado a ejercer el derecho a explorar, no tiene sentido seguir adelante en un área que no va a poder ser explotable porque el proyecto nunca obtendrá una licencia ambiental. Conclusión: en una zona excluible nunca podrá llegar a adquirirse el derecho de explotación y por esta razón se hace necesario que el Estado suspenda las actividades y revoque el título.

Ahora bien, en este escenario podría presentarse a los inversionistas el caso de una expro- 
piación indirecta. En el tema minero, esta figura se presenta de facto cuando se da una expropiación administrativa por razones de utilidad pública o interés social para la realización de proyectos de carácter ambiental, o cuando se expide una norma o acto administrativo que establece zonas de reserva o manejo ambiental (Márquez, 2010). Al declarar y delimitar una de estas zonas, resulta evidente que el disfrute de los derechos de los inversionistas se ve afectado en cuanto a que no pueden ejercer sus derechos emanados del contrato de concesión. Esta situación plantea un problema para el titular del contrato de concesión minera legítimamente celebrado con el Estado, en tanto ve afectado su derecho al no ser posible ejecutarlo. Así las cosas, podría pensarse entonces que al delimitar una zona excluible sobre un área con títulos mineros, el Estado estaría incurriendo en una expropiación indirecta, por lo que debería de alguna manera indemnizar al contratista al no poder este disfrutar de los derechos que le fueron otorgados por medio del contrato de concesión.

\section{CONCLUSIONES}

A lo largo del presente trabajo se evidenció un debate que está "a la moda" en el ámbito nacional: un choque de trenes entre una locomotora minera obsesionada en lograr ingresos para la nación, carente de controles y políticas claras, y una pequeña máquina ambiental dispuesta a frenar la locomotora a como dé lugar. En esta tensión puede resumirse el problema planteado y desarrollado en esta investigación. Sin embargo, a ello se le suma un tercer factor que en este caso entra a ser parte del problema: los dere- chos de los particulares e inversionistas extranjeros que se ven menoscabados por la falta de coordinación entre los dos sectores.

El título minero otorgado por la autoridad concedente, que ha cumplido con los requisitos contemplados por la ley minera, deberá gozar de protección con el fin de que los derechos reconocidos a través de él y que ingresan al patrimonio de la persona no sean vulnerados injustamente. Si bien en la situación bajo análisis es claro que la protección del medio ambiente debe primar, no puede dársele una prevalencia absoluta pues no pueden desconocerse derechos adquiridos que fueron obtenidos por un particular de buena fe y con el lleno de requisitos legales. Si bien la situación de una licencia en trámite, cuyo reconocimiento es una mera expectativa del solicitante, y la de una licencia ya reconocida y perfeccionada legalmente que constituye un derecho adquirido son situaciones muy distintas, ambas merecen cierto grado de protección. La solución propuesta para cada uno de los escenarios es presentada desde la perspectiva de la inversión extranjera, y teniendo en cuenta que debe dársele el mismo tratamiento a los titulares mineros nacionales y extranjeros, considero pertinente que en la reforma al Código de Minas que se encuentra en trámite se prevea un régimen de transición completo, o una solución similar a la aquí propuesta, para todos los titulares mineros y para cada uno de los escenarios desarrollados con miras a brindar seguridad jurídica a los futuros solicitantes.

A manera de conclusión, es viable decir que el problema actualmente -y que se evidenció du- 
rante el desarrollo de este trabajo- es la falta de coordinación que existe entre las autoridades mineras y las ambientales. Comúnmente se ha pensado que estos dos temas deben siempre enfrentarse y no se ha logrado adoptar la posición de que el medio ambiente y la minería necesariamente deberían ir de la mano. En esta visión, la adecuada delimitación de las áreas excluibles de la minería debe contar con el apoyo efectivo de las autoridades mineras, para garantizar el desarrollo sostenible, la preservación del medio ambiente y, simultáneamente, permitir la explotación minera, respetando los derechos adquiridos y el debido proceso así como las expectativas de los inversionistas. Solo con esto se logrará un verdadero desarrollo sostenible en el que se integren, tanto el medio ambiente como la economía y el desarrollo del país.

Si el Gobierno pretende que la minería sea una de las locomotoras principales de la economía y el desarrollo del país, debe propender por la articulación del sector minero y el ambiental para que no se presenten problemas de este tipo, que lo único que hacen pensar a la sociedad civil es que se debe evitar la actividad minera a toda costa y a los inversionistas que no existen garantías y es mejor no apostarle a Colombia. Es contrario a la seguridad jurídica y al desarroIlo sostenible ofrecer una oportunidad de inversión que luego va a resultar inexistente y prohibida (Pereira, 2009). Por esta razón, es indispensable que la nueva institucionalidad minera, en cabeza de la Agencia Nacional Minera, y un Ministerio de Medio Ambiente fortalecido, trabajen de la mano para lograr organizar el desorden que se ha creado en la titulación minera y en la declaración de zonas excluibles de la minería, sin controles ni fundamentos suficientes.

\section{Bibliografía}

Alianzas para la sostenibilidad. (s. f). El boom minero en Colombia pone a pensar a América Latina. Consultado el 30 de marzo de 2012 en http://www.alisos.net/es/el-boom-mineroen-colombia-pone-a-pensar-a-america-latina

Álvarez, G. (2011). Las áreas protegidas en CoIombia. Bogotá: Universidad Externado de Colombia.

ANDI pide legislación que evite el conflicto entre sectores minero y ambiental. (31 de agosto de 2011). Revista Dinero. Consultado el 9 de mayo de 2012 en http://www.dinero. com/ negocios/articulo/andi-pide-legislacion-evite-conflicto-entre-sectores-minero-ambiental/134476

AngloGold Ashanti Colombia. (s. f). ¿Cuál es el impacto de la minería? Consultado el 13 de abril de 2012 en http://www.anglogoldashanti. com.co/saladeprensa/Paginas/impacto-mineria.aspx

Bejarano, S \& Cárdenas, B. (2012). Los tratados de inversión: aliados del inversionista extranjero. Mundo Minero. Consultado el 6 de mayo de 2012 en http://mundominero.com. co/2012/03/02/los-tratados-de-inversionaliados-del-inversionista-extranjero/

Cabrera, E., Romero, M., \& Ortiz, N. (2008). Informe sobre el estado de la biodiversidad en 
Colombia: 2006-2007. Bogotá: Instituto de Investigación de Recursos Biológicos Alexander von Humboldt. Consultado el 16 de abril de 2012 en http://www.humboldt.org.co/download/INSEB_2006-2007.pdf

Centro Internacional de Arreglo de Diferencias RelatiVAS A INVERSIONES (CIADI).

_. (30 de agosto de 2000). Metalclad Corporation vs. México. Laudo arbitral.

_. (29 de mayo 2003). Técnicas medioambientales Tecmed S.A. vs. México. Laudo arbitral.

_. (12 de mayo de 2005). CMS Gas Transmission Company vs. Argentina. Laudo arbitral.

_. (3 de octubre de 2006). LG \& E Energy Corp. vs. Argentina. Decisión sobre la responsabilidad.

Colombia, Congreso de la República.

_. (2000). Exposición de motivos al Proyecto de Ley No. 269 de 2000, mediante el cual se expide el Código de Minas, Ley 685 de 2001. Bogotá: Gaceta del Congreso No. 113.

_. (2007). Proyecto de Ley No. 010 de 2007 presentado por el Ministerio de Minas y Energía, por medio del cual se reforma la Ley 685 de 2001. Bogotá: Gaceta del Congreso No. 344.

Colombia, Consejo de Estado, Sala de lo Contencioso Administrativo.

_. Sección Primera. Sentencia del 12 de agosto de 1999. C.P. Juan Alberto Polo Figueroa. Expediente No. 5550.
_. Sección Tercera. Sentencia del 12 de agosto de 2002. C.P. Germán Rodríguez Villamizar. Expediente No. S-417.

_.. Sección Tercera. Sentencia del 3 de febrero de 2010. C.P. Enrique Gil Botero. Expediente No. 33187.

__. Sección Tercera. Sentencia del 23 de junio de 2010. C.P. Ruth Stella Correa Palacio. Expediente No. 30987.

Colombia, Corte Constitucional.

_.. Sentencia T-411 de 1992. M.P. Alejandro Martínez Caballero. Expediente T-785.

_.. Sentencia C-168 de 1995. M.P. Carlos Gaviria Díaz. Expediente D-686.

__. Sentencia T- 617 de 1995. M.P. Alejandro Martínez Caballero. Expediente T-78710.

_.. Sentencia C-029 de 1997. M.P. Alejandro Martínez Caballero. Expediente D-7168.

_.. Sentencia C-221 de 1997. M.P. Alejandro Martínez Caballero. Expediente D-1458.

__. Sentencia C-649 de 1997. M.P. Antonio Barrera Carbonell. Expediente D-1671.

__. Sentencia C-478 de 1998. M.P. Marco Gerardo Monroy Cabra. Expediente D-1945.

__. Sentencia C-671 de 2001. M.P. Jaime Araújo Rentería. Expediente Lat-191.

__. Sentencia C-339 de 2002. M.P. Jaime Araújo Rentería. Expediente D-3767. 
_. Sentencia C-781 de 2003. M.P. Clara Inés Vargas Hernández. Expediente D-4502.

__. Sentencia T-321 de 2007. M.P. Rodrigo Escobar Gil. Expediente T-1469144.

_.. Sentencia C-800 de 2008. M.P. Manuel José Cepeda Espinosa. Expediente D-7168.

__. Sentencia C-1194 de 2008. M.P. Rodrigo Escobar Gil. Expediente D-7379.

__. Sentencia C-443 de 2009. M.P. Humberto Antonio Sierra Porto. Expediente D-7419.

_.. Sentencia C-033 de 2011. M.P. Jorge Iván Palacio Palacio. Expediente D-8200.

__. Sentencia C-366 de 2011. M.P. Luis Ernesto Vargas Silva. Expediente D-8250.

Colombia, Corte Suprema de Justicia, Sala de Casación Civil.

_.. Sentencia del 17 de marzo de 1977.

_.. Sentencia del 25 de junio de 2009. M.P. WiIliam Namén Vargas.

Colombia, Ingeominas. (2011). Irregularidades en la titulación. Información Minera de Colombia. Consultado el 6 de mayo de 2012 en http://www.imcportal.com/contenido.php?o ption $=$ shownews $\&$ newsid $=6244 \&$ render $=p a$ ge

Colombia, Instituto de Investigación en Recursos Biológicos Alexander von Humboldt. (18 de marzo de 2010). Concepto técnico perti- nente a la delimitación y caracterización de los ecosistemas de páramo. Oficio No. 2010028440-0.

Colombia, Ministerio de Ambiente, Vivienda y Desarrollo Territorial. (2010). Minería en zonas de protección ambiental. Consultado el 10 de enero de 2012 en http://www.infoandina. org/node/28477

Colombia, Ministerio de Minas y Energía

. (s. f). Memorias del Congreso Nacional de Minería 2006-2007, Sección B: Sector Minas. Consultado el 9 de mayo de 2012 en http:// www.minminas.gov.co/minminas/downloads/UserFiles/File/Sector\%20Minas $\% 20$ 07.pdf

_. (14 de febrero de 2008). Exploración y explotación en áreas de reserva forestal. Concepto No. 2008-003101.

_. (27 de mayo de 2011). Concepto previo para la declaración de zonas de exclusión. Concepto No. 2011-018889.

Colombia, Ministerio de Minas y Energía \& Ministerio de Medio Ambiente. (2002). Guía Minero-Ambiental de Exploración. Bogotá.

Colombia. Procuraduría Delegada pasa asuntos Ambientales y Agrarios de la Procuraduría General de la Nación. (22 de diciembre de 2002). Concepto relativo a la delimitación de zonas de páramo. Oficio No. 2010-06721.

Comisión de las Naciones Unidas para el Derecho MerCANTIL INTERNACIONAL (CNUMDI). 
_. (3 de septiembre de 2001). CME vs. República Checa. Laudo Parcial.

_. (15 de noviembre de 2004). Gami Investments Inc. Vs. México. Laudo arbitral.

- (17 de marzo de 2006). Saluka Investments vs. República Checa. Laudo parcial.

ConstrudATA. (2011). Sustracción de áreas en zona de reserva forestal. Consultado el 23 de mayo de 2012 en http://www.construdata.com/BancoConocimiento/S/sustraccion2011/sustraccion2011.asp

Díez-Hochleitner, J. (2010). La eficacia de los tratados de protección de inversiones extranjeras. Madrid: Real Instituto de Estudios Internacionales y Estratégicos. Consultado el 2 de mayo de 2012 en http://www.realinstitutoelcano.org/calendarios/Diez-Hochleitner.pdf

Dolzer, R. \& Schreuer, C. (2008). Principles of International Investment Law. London: Oxford University Press.

Environmental LaW Institute. (1995). Mecanismos para regular el impacto ambiental de la minería en los Estados Unidos. Consideraciones de un Régimen Jurídico ambiental para la minería en Argentina. Buenos Aires: Estudio Analítico No. 5.

FIORE, P. (1927). De la irretroactividad e interpretación de las leyes. Madrid: Editorial Reus.

Flores, O. (2011). La licencia ambiental de Greystar en Santurbán en entredicho. Consultado el 20 de mayo de 2012 en http://notia- gen.wordpress.com/2011/02/24/la-licenciaambiental-de-greystar-en-entredicho/

Greystar tan atractiva como riesgosa. (9 de julio de 2010). Revista Dinero. Consultado el 5 de mayo de 2012 en http://www.dinero.com/ inversionistas/articulo/greystar-tan-atractivacomo riesgosa/99065

Nadie quedará contento: entrevista al ministro de Minas y Energía, Mauricio Cárdenas Santamaría. (2011). Especial Revista Semana: Colombia Minera. Bogotá.

Márquez, N. (2010). La relación entre la cláusula de resolución de disputas del contrato de concesión colombiano y los compromisos adquiridos. Bogotá: Peña Mancera Abogados. Consultado el 3 de mayo de 2012 en http://www. pmabogados.co/es/component/k2/item/8la-relaci\%C3\%B3n-entre-la-cl\%C3\%A1usulade-resoluci\%C3\%B3n-de-disputas-del-contrato-de-concesi\%C3\%B3n-colombiano-y-loscompromisos-adquiridos

OtERO, D. (2012). El sector energético-minero y la economía colombiana. Bogotá: Instituto de Estudios para el Desarrollo y la Paz. Consultado el 7 de mayo de 2012 en http://www.indepaz.org.co/wp-content/uploads/2012/04/ Elsectorenerg\%C3\%A 9tico-minero-ylaeconom\%C3\%ADa-colombiana.pdf

PÁEz, M. (2009). La expropiación indirecta frente al CIADI: consideraciones para la autorregulación de los actos administrativos de los Estados. Revista de Estudios Internacionales. Santiago de Chile: Universidad de Chile. Con- 
sultado el 2 de mayo de 2012 en http://www. revistas.uchile.cl/index.php/REl/article/viewFile/14421/18979

Pardo, A. (s.f). Licencia Ambiental de Greystar: una decisión trascendental para el desarroIlo de nuevos proyectos en Colombia. Bogotá: Colombia Punto Medio. Consultado el 19 de mayo de 2012 en http://www.colombiapuntomedio.com/Portals/O/BannerHome/ Documentos/Audiencia\%20Publica\%20Paramo\%20de\%20Saturban.pdf

Pereira, A. (2009). Seguridad jurídica, inversión y medio ambiente. Periódico Al Derecho. Bogotá: Universidad de los Andes, Facultad de Derecho. Consultado el 14 de mayo de 2012 en http://periodicoalderecho.com/ index.php?option=com_content\&view=ar ticle\&id=218: seguridad-juridica-inversiony-medio-ambiente\&catid=13:blog-alvaropereira\&ltemid $=19$

Reyes, E. (2010). La esperanza de Santurbán. Consultado el 9 de mayo de 2012. en http:// www.imcportal.com/contenido.php?option=s hownews\&newsid $=5029 \&$ render $=$ page

Rodado, C. (2011). Gobierno reitera política minera frente a Greystar: comunicado del ministro de Minas y Energía. Bogotá: Censat Agua Viva. Consultado el 18 de mayo en http://www.censat.org/articulos/10030- noticia/10171-gobierno-reitera-politica-minera-frente-a-greystar

Rodríguez, M. (25 de abril de 2012). Cara y cruz sobre el medio ambiente. Revista Semana. Consultado el 20 de mayo de 2012 en http:// www.semana.com/nacion/cara-cruz-sobremedio-ambiente/176123-3.aspx

Sánchez Pérez, G. (2002). Desarrollo y medio ambiente: una mirada a Colombia. Revista de Economía y Desarrollo de la Fundación Universidad Autónoma de Colombia, Vol. 1, p. 1. Consultado el 29 de marzo de 2012 en http://www.fuac.edu.co/revista/M/seis.pdf

SCHILL, S. (2006). Fair and and Equitable Treatment under Investment Treaties as an Embodiment of the Rule of Law. New York: NYU Law. Consultado el 24 de mayo de 2012 en http://www.iilj.org/publications/ documents/2006-6-GAL-Schill-web.pdf

VIANA, M.J. (2007). El principio de confianza legítima en el derecho administrativo colombiano. Bogotá: Universidad Externado de Colombia.

VIVERO, F. de. (2004). La protección de la confianza legítima y su aplicación en la contratación estatal. Revista de Derecho Público No. 17. Bogotá: Universidad de los Andes, Facultad de Derecho. 